Perla BARTALOŠOVÁ

\title{
REDEFINOVANIE SOCIÁLNEJ SKUPINY SENIOROV NA ZÁKLADE NOVÝCH PRÍSTUPOV V JAZYKOVEDE ${ }^{1}$
}

\section{Redefinition the Social Group of Old Peoples on Basis of New Approaches in Linguistic}

Keywords: redefinition, social group, old people, intergenerational communication, interactive stylistic, interactive sociolingvistic

Contact: Univerzita Komenského v Bratislave; bartalosov13@uniba.sk

\section{Úvod}

Ciel’om predkladaného príspevku je na základe nových prístupov v jazykovede redefinovat' sociálnu skupinu seniorov. Doterajšie definície totiž celkom neodzrkadl'ujú reálny obraz seniorov, ked’že ten sa v čase globalizácie relativizuje, pretože sa kvalitatívne mení aj vnútorná štruktúra l'udí nad 65 rokov. Je potrebné, aby sa vedecké poznanie posunulo $\mathrm{k}$ autentickejšiemu reflektovaniu reálnej situácie. $\mathrm{K}$ tejto redefinácii pritom využijem nové prístupy $\mathrm{v}$ jazykovede $\mathrm{z}$ oblasti interakčnej štylistiky, resp. sociolingvistiky.

\section{Definície seniorov}

Už v samotnom úvode tejto kapitoly je potrebné zdôraznit, že pojem senior je pomenovanie, ktoré sa v posledných desiatkach rokov začalo používat' vo verejnom, aj odbornom diskurze ako synonymum pre označenie starého človeka. Môžeme pritom skonštatovat', že sa na dané pomenovanie zatial' neviažu žiadne citovo hodnotiace konotácie. Termín senior nahradzuje a zastrešuje iné terminologické vymedzenia, ktoré vznikli na pôde lekárskych, psychologických, sociologických a iných vedných disciplín na označenie staršieho človeka (Čornaničová 2007: 10). Jedným z takých pomenovaní

\footnotetext{
${ }^{1}$ Príspevok vznikol v rámci riešenia projektov VEGA 2/0014/19 Diskriminačná inštrumentalizácia jazyka a APVV 18-0176 Sociálna inklúzia kultiváciou používania jazyka.
} 
je aj výraz geront ${ }^{2}$, ktorý označuje osobu v postproduktívnom veku (Bartalošová 2018:

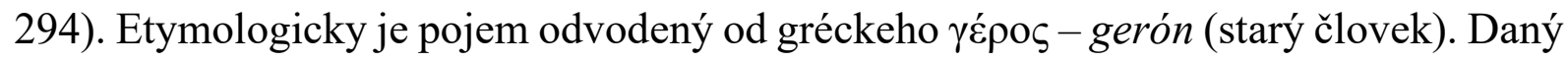
výraz sa nachádza aj v pomenovaniach rôznych disciplín, napr. gerontológia (v rámci lekárskych vied), alebo sociálna gerontológia ${ }^{4}$ ( $\mathrm{v}$ rámci sociálnych vied), $\mathrm{v}$ niektorých prípadoch sa $\mathrm{s}$ ním stretávame aj $\mathrm{v}$ rámci pomenovania odvetvia jazykovedy venujúceho sa jazyku seniorov - gerontolingvistika (Bartalošová 2018: 294). Práve v prípade výrazu geront môžeme hovorit' o postupnom navrstvení negatívnej konotácie, pretože v bežnom jazyku sa daný výraz používa skôr s pejoratívnym nádychom, napr. „Chorý štát, ktorý podporuje gerontov na úkor dorastu! !“. Je možné predpokladat', že aj vd’aka jeho pejoratívnemu nádychu sa v bežnom diskurze, aj v odbornej literatúre používa viac pojem senior. Ďalším pomenovaním je výraz starší dospelí, ktorý pochádza z americkej tradície (edelry adults) (porov. Kemper 1987; Kohrt, Kucharczik 2003: 29). Ciel'om tohto príspevku však nie je zhrnút', akými výrazmi sa seniori v odbornom diskurze označujú, ale zhodnotit', čo je obsahom týchto synoným, ktoré sa používajú na označenie starších ludí. Otázkou je, kto sú seniori. Existuje viacero aspektov pri prístupoch $\mathrm{k}$ definícii seniorov. Môžeme spomenút štyri primárne faktory, ktoré sú v komplementárnom vzt'ahu ${ }^{6}$ a vplývajú na tieto definície:

a) biologický faktor - spočíva vo vonkajších a vnútorných zmenách, ktoré naznačujú starnutie organizmu. Podla týchto definícií sú seniormi tí starí l'udia, na ktorých sa prejavili vonkajšie zmeny starnutia organizmu (zošedivenie vlasov, zvráskavenie pokožky) alebo vnútorné zmeny spôsobené starnutím (zabúdanie; spomalené rozprávanie, porozumenie, činnosti; choroby).

b) administratívny faktor - definície ovplyvnené administratívnym faktorom charakterizujú seniorov ako l'udí, ktorí dovíšili istý kalendárny vek. Niektorí autori (porov. napr. Sýkorová 2007) uvádzajú vek 60 rokov ako hranicu, odkedy môžeme niekoho považovat' za seniora. $V$ posledných rokoch sa ohraničenie seniorského veku posunulo k hranici 65 rokov. Uvádzajú tak mnohí autori, napr. H. Haškovcová (2010) alebo P. Bartalošová (2018) a iní. Toto ohraničenie staroby je ovplyvnené vekom nástupu do dôchodku a taktiež je založené na priemernom veku, akého sa l'udia dožívajú (stredná dížka života). V rámci tejto administratívnej hranice sa neustále stretávame s posunom.

\footnotetext{
${ }^{2}$ V databáze Slovenského národného korpusu (prim-8.0-public-sane) sa výraz „geront“ nachádza len v 306 prípadoch (2020-04-29).

${ }^{3}$ Porov. Slovník súčasného slovenského jazyka $A-G$.

${ }^{4}$ Sociálna gerontológia sa venuje spoločenským, ekonomickým, legislatívnym a iným aspektom života v starobe.

${ }^{5}$ Príklad z databázy Slovenského národného korpusu - prim-8.0-public-sane (2020-04-29).

${ }^{6}$ Hoci tieto faktory sú v komplementárnom vzt’ahu, tak nie všetky definície musia zahŕňat' všetky z uvedených faktorov.
} 
d) sociálny faktor - definície ovplyvnené sociálnym faktorom charakterizujú seniorov na základe spoločenského obrazu o senioroch, ktorý sa spája so sociálnymi rolami seniorov. Tieto sociálne roly pozostávajú zo štandardizovaných stereotypov o senioroch, ktoré sú časovo a kultúrne relatívne ${ }^{7}$. Tieto stereotypy spoluvytvárajú spoločenský obraz o senioroch, ktorý zároveň ovplyvňuje aj komunikáciu s nimi. Treba však skonštatovat', že vplývajú nielen na to, akú podobu má komunikácia mladých so staršími l'ud'mi, ale aj na to, ako samotní seniori komunikujú. Spoločenský obraz o senioroch totiž ovplyvňuje aj ich sebaobraz (Bartalošová 2020a rukopis: 4). A. Kruse a E. Schmitt (2006) alebo L. Vidovićová (2006) či T. Tošnerová (2002) uvádzajú nasledujúce stereotypy o starších l'ud'och: „mnoho starých l’udí sa v súčasnom svete nevyzná; starí l'udia sú osamelí, starý človek už má najlepšie roky za sebou; starí l’udia predstavujú pre štátny rozpočet príliš vel'kú zát'až; väčšina starých l’udí od svojej rodiny očakáva príliš mnoho podpory a starostlivosti“.

d) psychologický faktor - kým sociálny faktor pri definíciách berie do úvahy obraz seniorov v diskurze, tak psychologický faktor kladie dôraz na sebaobraz seniorov. Na sebapoňatie seniora pritom vplýva to, akú má osobnost', či je aktívny/pasívny, avšak aj spoločenský obraz o senioroch, l’udia sa totiž okrem iného hodnotia aj na základe toho, ako ich vnímajú iní l'udia, ako ich vníma spoločnost'. Tento jav sa označuje ako odzrkadl'ujúce hodnotenie (Brown 1998: 2). Sebavnímanie seniorov je na jednej strane ovplyvnené štandardizovanými stereotypmi o senioroch, na druhej strane ich osobnost'ou. Aktívnejší seniori môžu mat' pozitívnejšie sebahodnotenie a pozitívnejší vzt'ah k novým veciam, a naopak, pasívnejší seniori môžu byt' viac depresívni a môžu mat' tendenciu prepadat' role seniora, ktorý je závislý od svojho okolia, cíti sa zbytočný a nepovažuje za potrebné osvojit’ si nové, cudzie výrazy (porov. Bartalošová 2020a).

\section{Typy seniorov na základe príkladov z vlastného výskumu ${ }^{8}$}

Interakčná štylistika v komunikačno-pragmatickom rámci reorientuje záujem štylistiky v komunikačno-pragmatickom rámci na sféru každodennej komunikácie, na bežný prejav, ktorý sa skúma kvalitatívnymi výskumnými metódami (Orgoňová, Bohunická

\footnotetext{
${ }^{7}$ To znamená, že v minulosti sa mohli so seniormi spájat' iné stereotypy, napr. považovali sa za múdrych l'udí, ktorí predávali skúsenosti z generácie na generáciu, avšak dnes pod vplyvom vzniku nových informačných technológií sa tento stereotyp prehodnotil. Zároveň môžu v iných kultúrach (napr. v Afrike alebo v Ázii) vnímat' seniorov inak ako na Slovensku.

8 Výskum vznikol v rámci písania dizertačnej práce s názvom Jazyk seniorov $\mathrm{z}$ hl'adiska sociolingvistiky. Rozhovory som realizovala $\mathrm{v}$ júli až v novembri 2018 na vzorke 22 respondentov nad 65 rokov v rámci kvalitatívnej metodológie výskumu podl'a téz J. Hendla (2005), alebo tiež H. Garfinkela (1967) a konverzačných analytikov. Kvalitatívny výskum spočíva v tom, že nejde o zist'ovanie štatisticky relevantných názorov v opozícii „áno - nie“, ale o vnáranie sa do prípadových štúdií na báze osobných rozhovorov výskumníka s respondentmi v snahe o dôkladné empirické sondy do sociálnych javov bežného života.
} 
2018). V rámci medzigeneračnej komunikácie možno hovorit' o dvoch klúčcových konceptoch, a to o akomodácii, napríklad hovoriaceho (v prízvuku, vo výbere slov, prozódii, neverbálnej komunikácii, či v iných zložkách) a o asimilácii, v rámci ktorej sa hovoriaci neprispôsobuje prijímatel'ovi, ale udržiava si vlastný štýl prejavu. V komunikácii mladých so seniormi môžeme hovorit' napr. o príklade, ked' mladí v komunikácii so seniormi nepoužívajú anglicizmy, lebo predpokladajú, že seniori tieto výrazy nepoznajú (Bartalošová 2020b rukopis). V nasledujúcej časti exemplifikujeme dva typy starších l'udí nad 65 rokov, ktorých rozlišujeme podl'a ich spôsobu prejavu (najmä podla použivania anglicizmov v ich prejave a využivania 1. osoby množného čísla alebo 3. osoby množného čísla v prípade rozprávania o senioroch).

\section{a) Príklad z prejavov „pasívnych“ seniorov, ktorí nepoužívajú anglicizmy}

Medzi respondentmi sa našli takí seniori, ktorí uvádzali, že nechcú, aby s nimi mladí l’udia používali anglicizmy, lebo im nerozumejú. Zároveň jedna respondentka reagovala hnevom, ked' sa počas nakupovania stretla s takým tovarom, na ktorom boli len anglické nápisy: $\mathrm{R} 1^{9}$ : „To sa hnevám, lebo my tomu nerozumieme“. „Ja im nerozumiem a hnevám sa za to! Aj na obchodoch nápis! Ked' je na obchode nápis, čert to ber, ale ked' je aj na tovare a nie je tam po slovensky uvedené, tak by som to hodila niekam do kúta ${ }^{10 ،}$. Respondentka vo svojom prejave generalizuje a hovorí z perspektívy seniorskej skupiny v 1 . osobe množného čísla.

\section{b) Príklady aktívnych starších l'udí používajúcich anglicizmy vo svojom} prejave

Viacero starších l’udí v rámci výskumného súboru cestovali, a to nielen $\mathrm{v}$ rámci Slovenska, ale aj do zahraničia na dovolenky, napr. v rámci Európy, Ameriky, Afriky alebo Ázie. Respondentka č. 2 uvádza, že na dovolenke v Turecku nemusela ovládat' angličtinu: „S tým, že sme boli ôsmi alebo desiati - my sme mali tú slovenskú komunikáciu a s nimi sme sa nepotrebovali komunikovat', čo potrebujete jedlá, obedy, ran̆ajky a večere tam bolo všetko, ultra al inkluzív (mienené ultra all inclusive)“. V d’alšom svojom vyjadrení využíva viacero nových výrazov: Napr.: R2: „Dávam si napriklad čia (mienené chia) semienka (...) najprv to dám do smú:tí: (mienené smoothie $)^{“}$.

\footnotetext{
${ }^{9}$ Respondentka č. 1 je 85 -ročná žena, ktorá už je na dôchodku. Žije v Bratislave. Autorka respondentku predtým nepoznala. Spoznali sa počas realizácie rozhovoru. Rozhovor bol nahrávaný v oddelení dlhodobo chorých v Špecializovanej geriatrickej nemocnici v Podunajských Biskupiciach (Bratislava II).

${ }^{10}$ Ukážky z rozhovorov uvádzam v prepise na základe odbornej literatúry: Kaderka, P., Svobodová, Z. Jak přepisovat audiovizuální záznam rozhovoru. Manuál pro přepisovatele televizních diskusních pořadů. In: Jazykovědné aktuality. Praha: Jazykovědné sdružení České republiky, 2006 (43/3), s. 18-51. Dostupné na: http://www.jazykovednesdruzeni.cz/JA0634.pdf.
} 
Ďalej sme sa v prejavoch niektorých starších respondentov stretli s ageizmom ${ }^{11}$. $\mathrm{Na}$ otázku, či by slovník anglicizmov pomohol starším l’ud’om pochopit' anglicizmy, ktoré sa v súčasnosti v každodennej komunikácii vyskytujú, odpovedal: R3 ${ }^{12}$ : „myslím, že nie, lebo seniori majú problém zapnút' si mobil a v ňom si to pozriet' a nie si ešte $v$ nejakom slovniku hl'adat ${ }^{\star \star}$. Daný respondent má 65 rokov, zatial' sa však nevníma ako senior, nestotožňuje so stereotypmi, ktoré sa spájajú so sociálnou rolou seniora, a preto sa ani nepovažuje za člena tejto sociálnej skupiny. Môžeme si pritom všimnút', že o senioroch hovorí v 3. osobe množného čísla: „oni““.

\section{Doterajšie zistenia a redefinácia seniorov}

Je možné skonštatovat', že na to, kto je v spoločnosti vnímaný ako senior, vplývajú hlavne štyri primárne faktory, a to a) biologický vek (biologické zmeny, vonkajšie a vnútorné zmeny spôsobené starnutím organizmu), b) kalendárny vek (administratívna veková hranica), c) spoločenský obraz o senioroch (štandardizované stereotypy) a d) sebapoňatie seniora (typ osobnosti, či je človek aktívny/pasívny). V odbornej literatúre sa stretávame s definíciou seniorov najčastejšie na základe ich kalendárneho (chronologického) veku, pričom ten vnímame ako typický jav sociálneho konštruktu a túto definíciu hodnotíme ako nepostačujúcu. Zároveň si myslíme, že nestačí skonštatovat', že senior je človek, sktorým sa spájajú sociálne stereotypy spájajúce sa so sociálnou rolou seniora. Ako najdôležitejší faktor sa ukazuje byt’ práve faktor psychologický, ktorý vplýva na sebavnímanie, sebaobraz konkrétneho staršieho človeka. Treba skonštatovat', že v súčasnosti je na Slovensku početná skupina l’udí nad 65 rokov, ktorí sú aktívni, finančne nezávislí, v plnom sociálnom a pracovnom nasadení držiaci štandardne kontakt s napredovaním modernizácie, a teda osvojujú si aj bežné nové výrazy spájajúce sa s týmito inováciami, napr. učitelia alebo lekári. Bežní používatelia jazyka by v komunikácii sa takýmito l’ud'mi nezjednodušovali svoj prejav, z komunikácie by im totiž ani nevyplynula takáto potreba. Vek 65 rokov teda nemôžeme vnímat' ako striktnú hranicu, iba ako administratívny medzník. Ako hranicu nemôžeme vnímat' ani sivé vlasy, či spomalené zmysly. Dôležité je sebapoňatie seniora, ktorý sa ani nad 65 rokov nemusí vnímat' ako príslušník tejto sociálnej skupiny, čomu nasvedčujú aj uvedené príklady z vlastného výskumu. Preto ako seniorov vnímame tých l'udí vo vyššom veku, ktorí sú obyčajne už dôchodcovia (nepracujú) a sú pasívni, čo teda vplýva na sociálnu izoláciu týchto l'udí a na to, že nedržia krok s „napredovaním“ a neosvojujú si teda výrazy súvisiace s týmto „vývinom“. Títo

\footnotetext{
${ }^{11}$ Ageizmus je diskriminácia na základe veku.

${ }^{12}$ Respondent č. 3 je 65-ročný senior, ktorý je aktívny, cestuje. Stretáva sa s mladšími l'ud’mi. Autorka respondenta pred rozhovorom nepoznala.
} 
seniori sa cítia byt' súčastou tejto sociálnej skupiny a stotožňujú sa s vekovými stereotypmi viažucimi sa so sociálnou rolou tejto generačnej skupiny. To, či sa človek vníma ako príslušník seniorskej sociálnej skupiny, možno zistit' aj v podvedomých prejavoch človeka, ktorý vo svojom prejave pri komunikácii o senioroch hovorí o inej skupine, čo sa objavilo aj v príkladoch z nášho výskumu, napr. 65-ročný človek hovorí o senioroch $v 3$. osobe plurálu ,seniori sa už nič nové nenaučia“, a naopak, ak sa považuje za príslušníka skupiny seniorov, tak v prvej osobe plurálu: „,my už sa tie nové veci nenaučíme“.

\section{Záver}

Ciel'om predkladaného príspevku bolo na základe nových prístupov v jazykovede, a to kvalitatívnej analýzy medzigeneračnej komunikácie redefinovat' sociálnu skupinu seniorov. Na úvod príspevku sme uviedli a charakterizovali štyri základné faktory, ktoré vplývajú na definíciu seniorov, a to biologický, administratívny, sociálny a psychologický faktor. Následne sme uviedli príklady z vlastného výskumu, na základe ktorých sme ilustrovali dva možné obrazy starších l'udí. To, či sa l’udia cítia ako seniori závisí hlavne od osobnosti človeka a toho, či je aktívny/pasívny, či sa zaujíma o verejné dianie, či cestuje a pod. Na základe našich zistení sme na záver príspevku redefinovali sociálnu skupinu seniorov nasledovne: Sú to l'udia vo vyššom veku, ktorí sú obyčajne už dôchodcovia (nepracujú) a sú pasívni, čo teda vplýva na sociálnu izoláciu týchto l’udí a na to, že nedržia krok s „napredovaním“ a neosvojujú si teda výrazy súvisiace s týmto „vývinom“.

\section{Summary}

The aim of the presented paper was to redefine the social group of old people. At the beginning we introduced and characterized four basic factors that affect the definition of old people: biological, administrative, social and psychological factors. Subsequently we illustrated two possible images of older people based on examples from our own research. At the end of the article we redefined the social group of seniors as follows: They are older people who are usually retired (no longer working) and are passive, which affects the social isolation of these people and the fact that they do not keep up with "whether they are not adopting terms related to this "development". 


\section{Literatúra}

Bartalošová, P. Postoje seniorov $\mathrm{k}$ anglicizmom $\mathrm{v}$ slovenčine ( $\mathrm{Na}$ základe sociolingvistickej sondy z oblasti Trenčína). Slovenská reč. 2018 (83), s. 292310.

Bartalošová, P. Jazyk seniorov z hl’adiska sociolingvistiky. Bratislava: Veda. 2020a.

Bartalošová, P. Akomodačno-asimilačné procesy v intergeneračnej komunikácii. Slovenská reč. $2020 b$ (85). Rukopis.

Brown, D. J. The Self. New York: McGraw-Hill, 1998.

Čornaničová, R. Edukácia seniorov. Bratislava: Univerzita Komenského, 2007.

Garfinkel, H. Studies in Ethnomethodology. Los Angeles: University of California, 1967.

Hendl, J. Kvalitativní výzkum. Praha: Portál, 2005.

Kaderka, P., Svobodová, Z. Jak přepisovat audiovizuální záznam rozhovoru? Manuál pro přepisovatele televizních diskusních pořadů. Jazykovědné aktuality. 2006 $(43 / 3)$, s. 18-51.

Kemper, S. Life-span changes in syntactic complexity. Journal of Gerontology. 1987 (42), s. 323-328.

Kohrt, M., Kucharczik, K. „Sprache“ - unter besonderer Berücksichtigung von „Jugend“ and „Alter“. In: Fiehler, R., Thimm, C. (eds.) Sprache und Kommunikation im Alter. Radolfzell: Verlag für Gesprächsforschung, 2003, s. $17-37$.

Kruse, A., Schmitt, E. A multidimensonal scale for the measurement of agreement with age stereotypes and the salience of age in social interaction. Ageing Society. 2006 (26), s. 393-411.

Orgoňová, O., Bohunická, A. Interakčná štylistika. Bratislava: Univerzita Komenského v Bratislave, 2018.

Slovenský národný korpus - prim-8.0-public-sane. Bratislava: Jazykovedný ústav L'. Štúra SAV 2018. Dostupný na: http://korpus.juls.savba.sk.

Slovník súčasného slovenského jazyka. A-G. Buzássyová, K., Jarošová, A. (eds.) Bratislava: Veda, vydavatel'stvo Slovenskej akadémie vied, 2006. (kolektív autorov: L'. Balážová, K. Buzássyová, M. Čierna, B. Holičová, N. Janočková, A. (Adriana) Oravcová, A. (Anna) Oravcová, M. Petrufová, E. Porubská, A. Šebestová, A. Šufliarska, M. Zamborová). 
Sýkorová, D. Autonomie ve stárí: kapitoly z gerontosociologie. Praha: Sociologické nakladatelství SLON, 2007.

Tošnerová, T. Ageizmus - průvodce stereotypy a mýty o stář́i. Praha: Ambulance pro poruchy paměti, Ústav lékařské etiky 3. LF UK a FN Královské Vinohrady, 2002.

Vidovićová, L. Stárnutí, věk a diskriminace - nové souvislosti. Brno: Masarykova univerzita, Mezinárodní politologický ústav, 2006.

(c) $(\$$ The article is accessible in open access mode under licence CC BY-NC-ND

Creative Commons Attribution-NonCommercial-NoDerivatives 4.0 